\title{
Reproduction and size at first maturity in a Mediterranean exploited Callista chione bivalve bed
}

\author{
Eve Galimany ${ }^{1,2,3}$, Marc Baeta ${ }^{2}$, Mercè Durfort ${ }^{4}$, Jordi Lleonart ${ }^{2}$, Montserrat Ramón ${ }^{1,2}$ \\ ${ }^{1}$ Instituto Español de Oceanografía, Centre Oceanogràfic de Balears, Moll de Ponent s/n, 07015 Palma de Mallorca, Spain. \\ ${ }^{2}$ Institut de Ciències del Mar - CSIC, Passeig Marítim de la Barceloneta, 37-49, 08003 Barcelona, Spain. \\ E-mail: mramon@icm.csic.es \\ ${ }^{3}$ Current address: Smithsonian Marine Station at Fort Pierce, 701 Seaway Drive, Fort Pierce, Florida 34949, USA \\ ${ }^{4}$ Departament de Biologia Cel-lular, Facultat de Biologia, Universitat de Barcelona, Avda. Diagonal 645, \\ 08028 Barcelona, Spain.
}

\begin{abstract}
Summary: The smooth clam Callista chione is an Atlantic-Mediterranean species that is commercially exploited in several European countries. Several aspects of its reproduction were studied in a coastal location of the northwestern Mediterranean as a tool for sustainable fisheries management. Gonadal development was classified into 6 different stages, ranging from immature to degradation of the remaining sexual structures. Results showed that $C$. chione was able to reproduce throughout the year but a main spawning period occurred in spring. First records of hermaphrodites were found for this species. The mature spermatozoa measured $4.70 \pm 0.66 u \mathrm{~m}$ (without the flagellum), including a very short acrosome of $0.75 \pm 0.09 u \mathrm{~m}$. The mid-piece of the spermatozoa had a mitochondrial sheath composed of five mitochondria. Ripe oocytes ranged from 60 to 80 $\mu \mathrm{m}$ in length. Size at first maturity $\left(\mathrm{SL}_{50}\right)$ was estimated for the first time in a Mediterranean population, showing values of $30.26 \mathrm{~mm}$ in $2005-2006$ but only $21.45 \mathrm{~mm}$ in 2014 .
\end{abstract}

Keywords: gonads; first maturity; hermaphroditism; Veneridae; commercial mollusks.

Reproducción y talla de primera madurez en un banco de Callista chione explotado en el Mediterráneo

Resumen: La concha fina Callista chione es una especie atlántico-mediterránea comercialmente explotada en distintos países europeos. Se estudiaron varios aspectos de su reproducción en una localidad costera del noroeste Mediterráneo como herramienta para la gestión sostenible de su pesquería. El desarrollo gonadal se clasificó en 6 estadios distintos, que engloban desde individuos inmaduros a la degradación de las estructuras sexuales remanentes. Los resultados mostraron que C. chione se podía reproducir durante todo el año con un periodo de máxima puesta en primavera. Se observaron hermafroditas de esta especie por primera vez. Los espermatozoos maduros midieron $4.70 \pm 0.66 u \mathrm{~m}$ (sin el flagelo) incluyendo un corto acrosoma de $0.75 \pm 0.09 \mu \mathrm{m}$. La pieza media de los espermatozoos estaba compuesta por 5 mitocondrias. Los ovocitos maduros median entre 60-80 $\mu \mathrm{m}$ de longitud. La talla de primera maduración $\left(\mathrm{SL}_{50}\right)$ se estimó por primera vez en una población del Mediterráneo, hallando valores de $30.26 \mathrm{~mm}$ en 2005-2006 pero solamente de $21.45 \mathrm{~mm}$ en 2014.

Palabras clave: gónadas; primera maduración; hermafroditismo; Veneridae; moluscos comerciales.

Citation/Como citar este artículo: Galimany E., Baeta M., Durfort M., Lleonart J., Ramón M. 2015. Reproduction and size at first maturity in a Mediterranean exploited Callista chione bivalve bed. Sci. Mar. 79(2): 233-242. doi: http://dx.doi. org/10.3989/scimar.04155.13A

Editor: J.A. Cuesta.

Received: September 25, 2014. Accepted: April 10, 2015. Published: May 14, 2015.

Copyright: () 2015 CSIC. This is an open-access article distributed under the Creative Commons Attribution-Non Commercial Lisence (by-nc) Spain 3.0.

\section{INTRODUCTION}

Bivalves can provide a wide range of ecosystem functions. For example, they can improve the water quality of the ecosystems due to their filter-feeding capacity to mitigate the effects of eutrophication (Valli et al. 1994, Ostroumov 2005, Coen et al. 2007, Lindahl and Kollberg 2009). Bivalves also promote the structures of ecosystems with their biomass, skeletons and burrowing activity (Dame 1996) and therefore contribute to the increase in habitat heterogeneity for fishs and invertebrates (Gutiérrez et al. 2003, Coen et al. 2007). They can also transfer chemical elements and nutrients from the water and seston to other trophic levels and to 
the sediments, linking benthic and pelagic ecosystems (Prins et al. 1998, Newell 2004). Moreover, many bivalve species play important economic roles through fisheries and aquaculture.

The smooth clam Callista chione (Linnaeus, 1758) is a venerid bivalve that inhabits coarse sand bottoms in the east Atlantic Ocean, from the UK down to Morocco, the Archipelago of Azores, Madeira and the Canary Islands, although it is more common in the Mediterranean Sea than elsewhere (Poppe and Goto 1993, Gofas 2013). The shell length can reach $100 \mathrm{~mm}$ and it is glossy and easily distinguished from any other European sea shell (Poppe and Goto 1993). The importance of $C$. chione is both ecological and economical. Baeta and Ramón (2013) reported that this bivalve was one of the main preys of the seastar species of the genus Astropecten in the western Mediterranean Sea, and they are also consumed by other invertebrates such as the gastropod Hexaplex trunculus (Morton et al. 2007) and the cephalopod Octopus vulgaris (Fiorito and Gherardi 1999). C. chione is commercially exploited and consumed in Portugal and the Mediterranean Sea (Gaspar et al. 2001, Tirado et al. 2002, Metaxatos 2004, Pubill et al. 2011, Baeta et al. 2014) where it is captured with small boats using different types of artisanal dredges. One of the main coastal shellfish areas where a major clam fishery targeted the smooth clam is the Maresme coast, located to the northeast of Barcelona (NW Mediterranean Sea). As reported by Baeta et al. (2014), the local administration commissioned a study of the smooth clam bed status in 2004 as a consequence of the decline in catches. The results prompted a temporary bed closure and an annual closing season in spring for the following four years. However, the population did not recover and the main causes of the huge reduction of the resource were overfishing and sand dredging (Baeta et al. 2014).

The reproductive system of bivalves consists of a pair of gonads, which in some species are fused in the middle (Galtsoff 1961). The gonads are made of branching tubules where gametes develop in the epithelial lining (Gosling 2003). The tubules join to form ducts leading into progressively larger ducts that terminate in a short gonoduct (Gosling 2003). Most of the bivalves are dioecious, that is, they have separate sexes. However, it is usually very difficult to distinguish the different gonads macroscopically, so the use of microscopic techniques is essential to differentiate sexes (Tirado et al. 2002). The reproductive cycle in bivalves involves gonadal development, ripeness of the gametes and spawning, but there is an enormous variation in the timing and duration of each stage both within and between species (Gosling 2003). Many exogenous (mainly temperature) and endogenous factors are involved in the reproduction processes. The role of these factors in the initiation and duration of the gametogenesis differs from their role in the timing and synchronization of spawning, a much briefer event (Seed and Suchanek 1992). The study of the reproductive cycle in bivalves is essential to understand the biology of the species and to develop an appropriate fisheries management. For example, size at first maturity is one of the parameters commonly evaluated to assess the management of fish and shellfish stocks (Walker 1992, Williams and Babcock 2005, Camacho-Mondragón et al. 2012).

The aim of this study was to investigate the reproductive cycle of $C$. chione in the Maresme coast (NW Mediterranean Sea) and to provide the first estimation of size at first maturity in a Mediterranean population. For the purpose we used histological techniques to study the reproductive stage, sex ratios and quantitative measurements to determine oocyte diameters. We also described the spermatozoa using scanning electron microscopy. Our research reports the first case of hermaphroditism in this species.

\section{MATERIALS AND METHODS}

\section{C. chione sampling}

Specimens of Callista chione were collected on the Maresme coast, northeast of Barcelona (Spain), in the northwestern Mediterranean Sea (between $41^{\circ} 18^{\prime} \mathrm{N}$, $2^{\circ} 20^{\prime \prime} \mathrm{E}$ and $\left.41^{\circ} 38^{\prime} \mathrm{N}, 2^{\circ} 50^{\prime \prime} \mathrm{E}\right)$ on board an artisanal fishing boat (10 m length; $100 \mathrm{HP}$ ) and between 5 and $30 \mathrm{~m}$ depth. The gear used was a modified commercial clam dredge (mouth width, $70 \mathrm{~cm}$; mouth height, 53 $\mathrm{cm}$; depth, $120 \mathrm{~cm}$ ) provided with a $12 \times 12 \mathrm{~mm}$ steel mesh size smaller than the commercial size to allow juvenile individuals to be caught.

The reproductive cycle was studied using 30 individuals collected monthly from January 2005 to January 2006, except for the month of August 2005, when the collection of the samples was not possible, and the month of October 2005, when the number of individuals studied was reduced to 20 .

The surface sea water temperature during the whole period of study was recorded hourly by the Wave Coastal Network of State Ports (REDCOS) (http:// www.sidmar.es/en/Services/Operational-Services/ RedCos.html) using the data from the buoy Barcelona II $\left(41.32^{\circ} \mathrm{N}, 2.20^{\circ} \mathrm{E}\right)$.

\section{Histological analysis}

In the laboratory, the bivalves were measured with an electronic caliper and dissected, and the gonadal tissues were fixed in a buffered formaldehyde solution at $4 \%$ for $24 \mathrm{~h}$. The tissues were then rinsed in tap water and transferred to $70 \%$ alcohol. The samples were dehydrated and embedded in paraffin. After processing, sections of 5- $\mu \mathrm{m}$ thickness were cut, placed in glass slides, stained using a hematoxylin-eosin staining procedure and examined under a light microscope. Sections were examined at $10 \times, 40 \times$ and $100 \times$ magnifications, sexed and assigned to a developmental stage according to Valli et al. (1994), i.e.: Stage 0, inactive, germinal cells are immature and the connective tissue cells are disperse in a matrix; Stage 1, early active, the gonad begins its formation with the appearance of little follicles in the connective tissue containing few germinal cells; Stage 2, late active, the gonad increases the number of follicles which contain cells in different 
developmental stages; Stage 3, ripe, the gonad is fully developed with round follicles containing ripe sexual cells and occupies most of the visceral mass; Stage 4, spawning period, the follicles release the gametes and might be empty; Stage 5, degradation, the follicles might have residual gametes and the remaining sexual cells and structures are reabsorbed.

\section{Size at first maturity}

The size at first maturity $\left(\mathrm{SL}_{50}\right)$ is defined as the length at which $50 \%$ of the population is mature. Specimens used for the microscopic analysis of gonadal sections (from 18.8 to $95.6 \mathrm{~mm}$ shell length and from January 2005 to January 2006) were employed for the $\mathrm{SL}_{50}$ estimation. The developmental Stages 3 and 4 were considered as mature individuals and Stages 0, 1,2 and 5 as immature for $\mathrm{SL}_{50}$ estimations. An additional sample of 234 specimens (ranging between 17 and $59 \mathrm{~mm}$ shell length) was analysed in May 2014. This month was selected because, according to the histological analysis done previously, most adult individuals were either ripe or spawning. The visceral mass was then teased apart and smears of the visceral wall with attached gonad were examined microscopically at 40x magnification. Individuals were considered to have mature gonads when (i) abundant motile sperm was observed in males and (ii) large, round oocytes with a well-defined surrounding gelatinous membrane were observed in females, according to previous studies (Metaxatos 2004).

\section{Description of the reproductive cells and oocyte measurements}

Male sexual cells were observed using a Hitachi S-3500 N scanning electron microscope located at the Institut de Ciències del Mar (CSIC), with an acceleration voltage of $15 \mathrm{kV}$, provided with back-scattered electron detector (BSE). None of the samples was coated. The size of nine spermatozoa and acrosome was measured randomly in 5 individuals during the ripening season, giving a total of 45 spermatozoa measured.

The size frequency distribution of oocyte diameters was studied monthly using the gonadal histological slides. Whenever possible, measurements involved ten females per month and reading 60 oocytes from each female using the Image-Pro Plus image analysis software package (Media Cybernetics, L.P.). To standardize the method, only oocytes with a visible nucleus were measured.

\section{Statistical analysis}

The sex ratio in the samples, expressed both as percentage of sexes and as number of males per female (M:F), was compared with parity (1:1) using the $\mathrm{Z}$ test for proportions. The relationship between the percentage of ripeness of the population and the water temperature was tested using the statistical software Statgraphics Plus (Manugistics, Inc., Rockville, MD, USA).
Table 1. - Characteristics of the analysed C. chione specimens: percentage of individuals at each gonadal stage (\% ind) and minimum (Min), maximum (Max) and average $( \pm \mathrm{SD})$ shell length $(\mathrm{mm})$.

\begin{tabular}{ccccc}
\hline Gonadal stage & \% ind & Min & Max & Average \\
\hline 0 & 2 & 56.26 & 57.89 & $57.08 \pm 0.71$ \\
1 & 7 & 31.00 & 66.80 & $49.22 \pm 9.97$ \\
2 & 14 & 33.55 & 76.94 & $59.58 \pm 8.48$ \\
3 & 30 & 41.16 & 91.46 & $66.26 \pm 9.08$ \\
4 & 30 & 40.04 & 95.60 & $65.16 \pm 10.60$ \\
5 & 17 & 18.80 & 82.65 & $52.09 \pm 13.51$ \\
\hline
\end{tabular}

Maturity relative frequencies and cumulative relative frequencies for 1-mm size intervals were computed, and the later was fitted to a logistic model from which the parameters were estimated minimizing the residual mean square between the observed data and the model.

\section{RESULTS}

\section{Gonadal cycle}

A total of 320 specimens of $C$. chione with a size range of between 18.8 and $95.6 \mathrm{~mm}$ were analysed for this study (Table 1). The smaller individuals measured were found in maturation Stages 1 or 5 (early active or degradation, respectively). The histological study showed that $C$. chione was able to reproduce throughout the year although a major spawning period was found in spring, specifically in May (Fig. 1A, B and C). Females seemed to have a slightly more advanced cycle than males and some spawning occurred in February, while males began in March, although there was a common major spawn in May (Fig. 1A, B). The monthly relative frequency of the gonadal stages of $C$. chione showed the simultaneous occurrence of different stages of development yearround, regardless of the sex (Fig. 1C). The gonadal maturation of the smooth clam population began in December and the gonads remained mainly ripe during February and March. In April, about 50\% of the population, mainly females, was spawning. The percentage of spawning individuals reached $90 \%$ in May, which was the most important spawning period of $C$. chione for both sexes at the site. From June to November at least four different gonadal stages were found per month, including very early stages of gonadal development to spawning and degradation of the gonads after spawning. The interstitial connective tissue had different stages of development according to the ripeness of the gonad. When gonads were not ripe and Stages 0 and 1 were found, the connective tissue was well developed, but it progressively disappeared as the gonadal follicles began to form (Fig. 2). After spawning and degrading of the remaining sexual structures, the interstitial connective tissue started to develop again.

Monthly average water temperature (Fig. 1C) showed minimum and maximum values of $12.4 \pm 0.01^{\circ} \mathrm{C}$ (March 2005) and 26.0 $\pm 0.24^{\circ} \mathrm{C}$ (August 2005). There was a significant relationship $(\mathrm{p}=0.0004)$ between the percentage of ripe individuals in the population and the water temperature (Fig. 3), that is, the lower the 

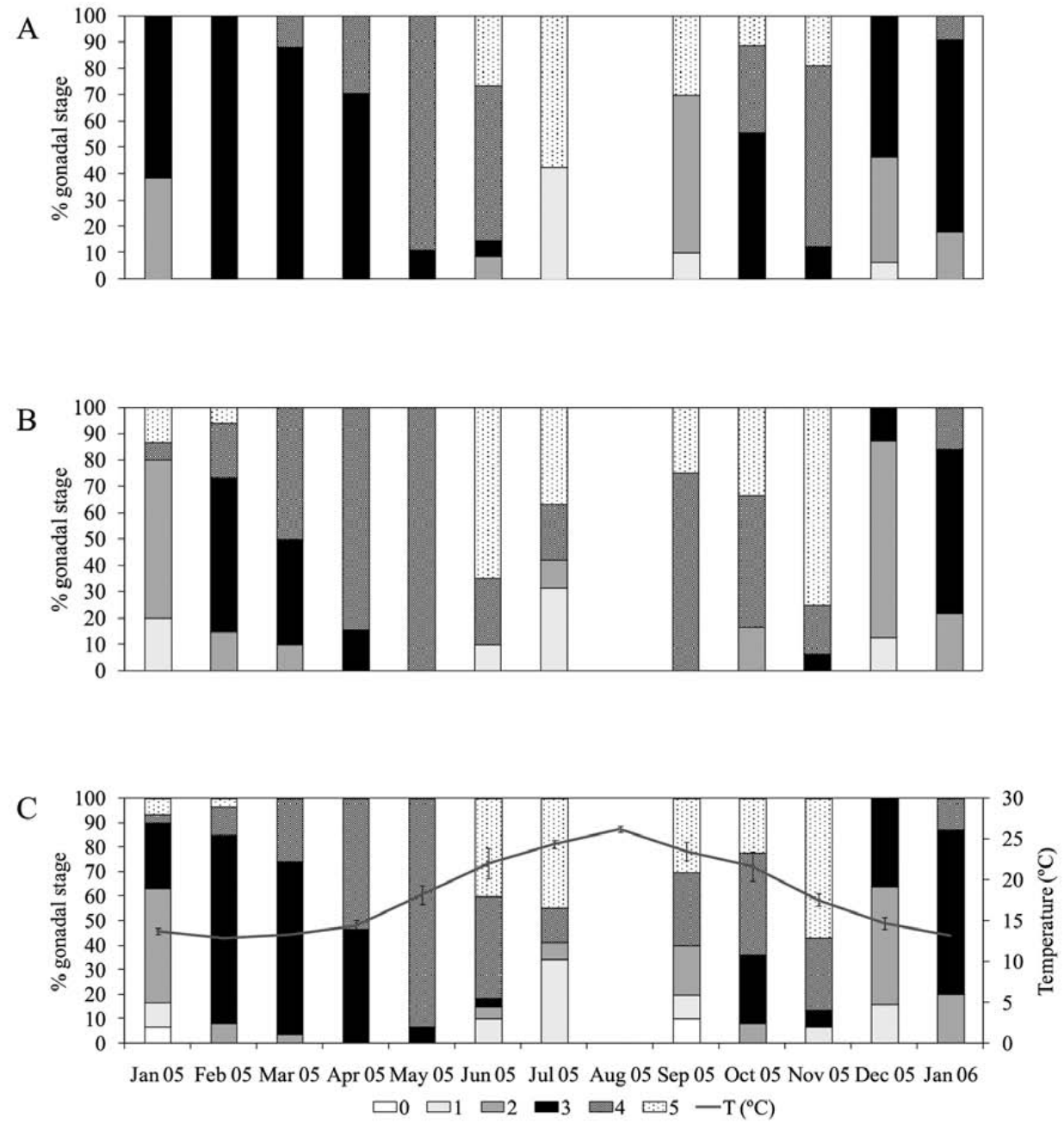

Fig. 1. - Monthly average temperature and relative frequency of the different gonad development stages throughout the period of study for males (A), females (B), and the whole population (C). Stage 0, inactive; Stage 1, early active; Stage 2, late active; Stage 3, ripe; Stage 4, spawning period; Stage 5, degradation.

temperature, the riper the population. The relationship found can be expressed as

$$
\begin{aligned}
\% \text { ripe } C \text {. chione }= & 308.72-98.53 \text { ln temperature; } \\
& \mathrm{R}^{2}=72.94
\end{aligned}
$$

\section{Sex ratio}

It was not possible to determine sex for only 7 individuals (sizes ranging from 55.4 to $77.2 \mathrm{~mm}$ length) collected in the months of July and October 2005, and January 2006. Sex ratio was 1:1 in 2005-2006 (157 males vs 156 females; $Z=0.06)$ and 2014 (109 males vs 95 females; $Z=0.98$ ). In 2014, it was not possible to determine sex in 30 individuals from the 237 analysed. The proportions of sexes were not significantly different $(Z=0.73)$ between 2005-2006 and 2014. The critical value for $\alpha=0.05$ is $Z(0.05)=1.96$; all obtained statistics were smaller.

We report for the first time the existence of hermaphrodites in $C$. chione. Within the histological samples we found five cases: two individuals from March 2005, two from September 2005, and one from January 2006 (Fig. 4). From the smear samples in 2014 we identified one hermaphrodite. The frequency of occurrence was $1.4 \%$ and $0.4 \%$ in $2005-2006$ and 2014 , respectively.

\section{Size at first maturity}

Size at first maturity was analysed microscopically from two data sets: histological slides of the gonad in 2005-2006 and smears of the gonad in 2014. The logistic model was fitted to both data sets minimizing the sum of squares of the differences between the frequencies observed and estimated by the model. In Table 2 the general statistics and the overall results are presented. Results for 2005-2006 showed that $\mathrm{SL}_{50}$ was $30.26 \mathrm{~mm}$. Nevertheless, mature females with a 20.6 $\mathrm{mm}$ length and mature males as small as $23.8 \mathrm{~mm}$ were observed. For $2014, \mathrm{SL}_{50}$ was $21.45 \mathrm{~mm}$. The residual mean square shows a better fitting of 2005-2006 data than 2014 data. Furthermore, comparing both fittings it can be seen that the estimated logistic growth parameter (r) is higher for 2014 data and lower for 2005-2006, meaning that the logistic curve is sharper for 2014; this can also be seen considering the difference between the quartiles $\mathrm{SL}_{75}-\mathrm{SL}_{25}, 13.8 \mathrm{~mm}$ for 2005-2006 and 9.5 


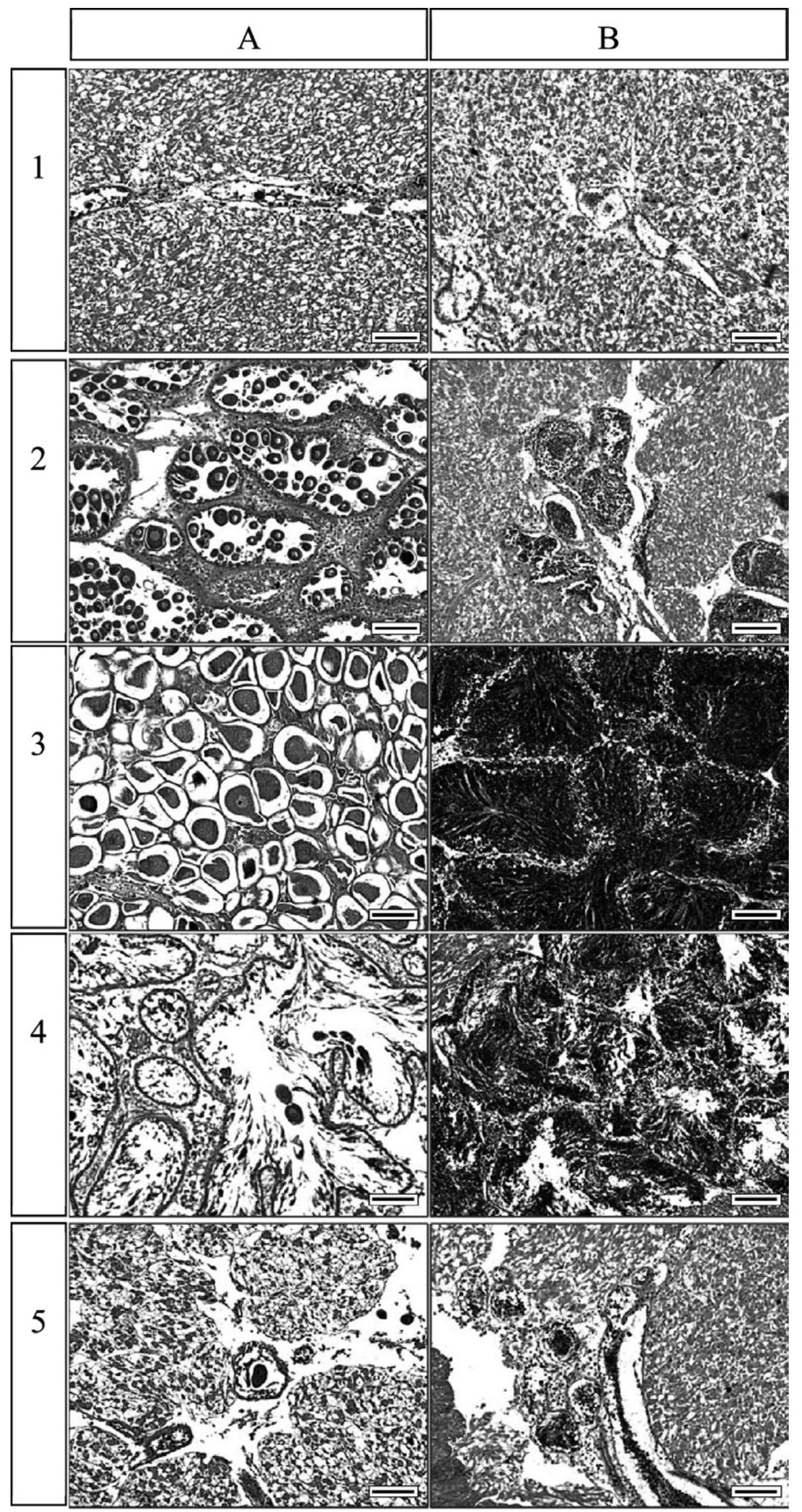

Fig. 2. - Histological sections of the gonads showing different gonad stages for both sexes. Columns: A, female sections; B, male sections. Rows: 1 , Stage 1; 2, Stage 2; 3, Stage 3; 4, Stage 4; 5, Stage 5. Scale bar measures $100 \mu \mathrm{m}$. 


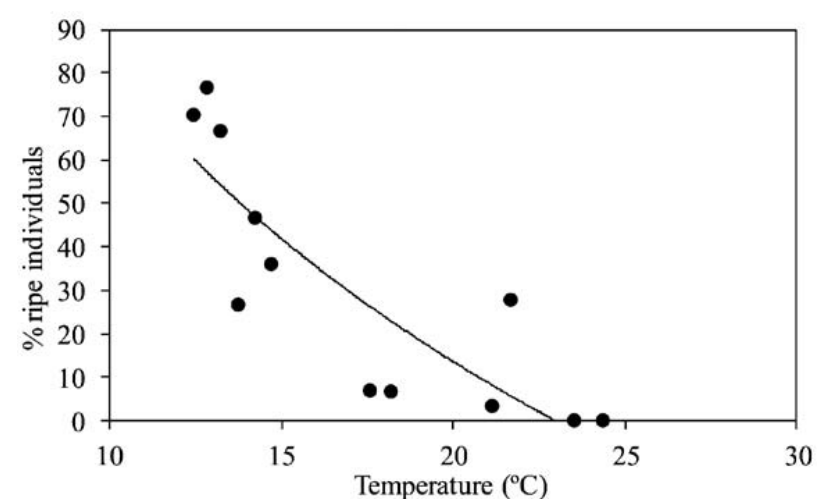

Fig. 3. - Relationship between the percentage (\%) of ripe individuals in the population and the water temperature $\left({ }^{\circ} \mathrm{C}\right)$.

Table 2. - Basic sample statistics and fitting values of the logistic model to estimate the size at first maturity $\left(\mathrm{SL}_{50}\right)$ for both sampling periods (years 2005-2006 and 2014).

\begin{tabular}{lrr}
\hline & $2005-06$ & 2014 \\
\hline Number of classes & 71 & 33 \\
Number of individuals measured & 320 & 234 \\
Lower observed length (mm) & 17 & 17 \\
Lower length with mature individuals (mm) & 18 & 19 \\
Higher length with immature individuals (mm) & 58 & 28 \\
Higher observed length (mm) & 95 & 59 \\
SL $_{25}(\mathrm{~mm})$ & 23.37 & 16.70 \\
LL $_{50}(\mathrm{~mm})$ & 30.26 & 21.45 \\
SL & 37.15 & 26.21 \\
r (growth parameter of the logistic model) & 0.1593 & 0.2309 \\
Residual mean square & 0.018 & 0.025 \\
\hline
\end{tabular}

$\mathrm{mm}$ for 2014. The size structure of the sampled specimens changed between 2005-2006 and 2014, with the biggest clams missing in the second period of the study (sizes between 59 and $95 \mathrm{~mm}$ length) because of their absence in the population.

\section{Description of the reproductive cell and oocyte measurements}

Mature spermatozoa measured 4.70 $\pm 0.66 \mu \mathrm{m}$ (Fig. 5) (without the flagellum), including a very short acro-

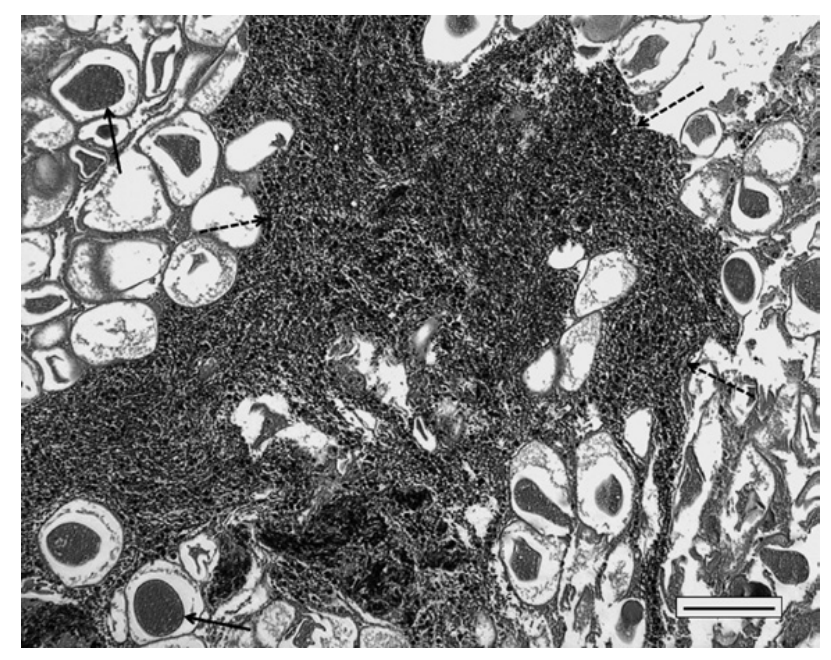

Fig. 4. - Histological section of the gonads of a hermaphrodite individual. Arrows point to mature oocytes; broken arrows point to the mass of sperm. Scale bar is $100 \mu \mathrm{m}$.

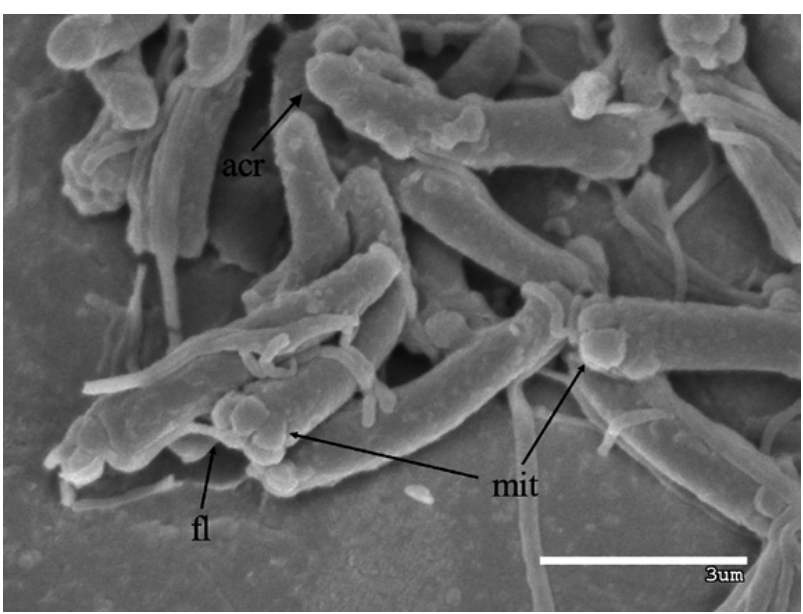

Fig. 5. - Scanning electron microscope image of a male gonad section. Acr, acrosome; fl, flagellum; mit, mitochondria. Scale bars shown in image.

some of $0.75 \pm 0.09 \mu \mathrm{m}$ length. The mid-piece of the spermatozoa has a mitochondrial sheath composed of five mitochondria; the tail emerged from the middle of the sheath.

Most of the oocytes observed in the histological samples were round and, when fully ripe, they were much hydrated (average diameter 58.48 $\pm 17.42 \mu \mathrm{m}$ ). Nevertheless, in Stages 2 and 4, oocytes were occasionally linked to the gonadal follicle through a peduncle (pedunculated oocytes) and their sizes ranged between 35 and $171.34 \mu \mathrm{m}$. Ripe oocytes from $C$. chione had a nucleus, which occupied much of the reproductive cell and was stained in pink with the stains used in our study. Inside the nucleus there was a nucleolus, which might seem bi-lobulated in some cases but was just the observation of the two components of the nucleolus: pars granulosa, with granules of rRNA and proteins; and pars fibrosa, with filaments of rRNA (Fig. 6).

The length frequency distributions of oocyte diameters according to sampling months are shown in Figure 7. For most of the months, the frequency distributions of oocyte diameters were polymodal, indicating female

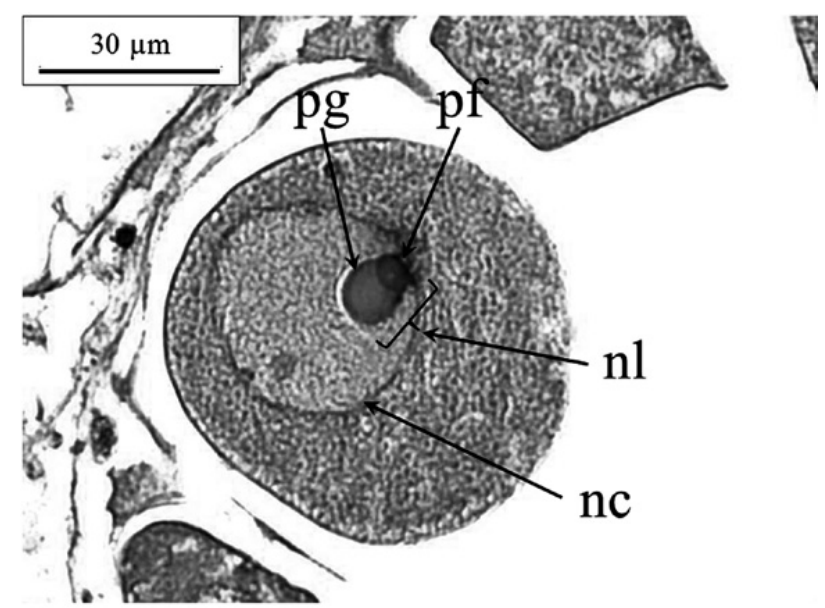

Fig. 6. - Optical micrographs of a ripe oocyte with a nucleus (nc) and a nucleolus (nl) and its two parts: pars granulosa (pg) and pars fibrosa (pf). Scale bars are $30 \mu \mathrm{m}$. 

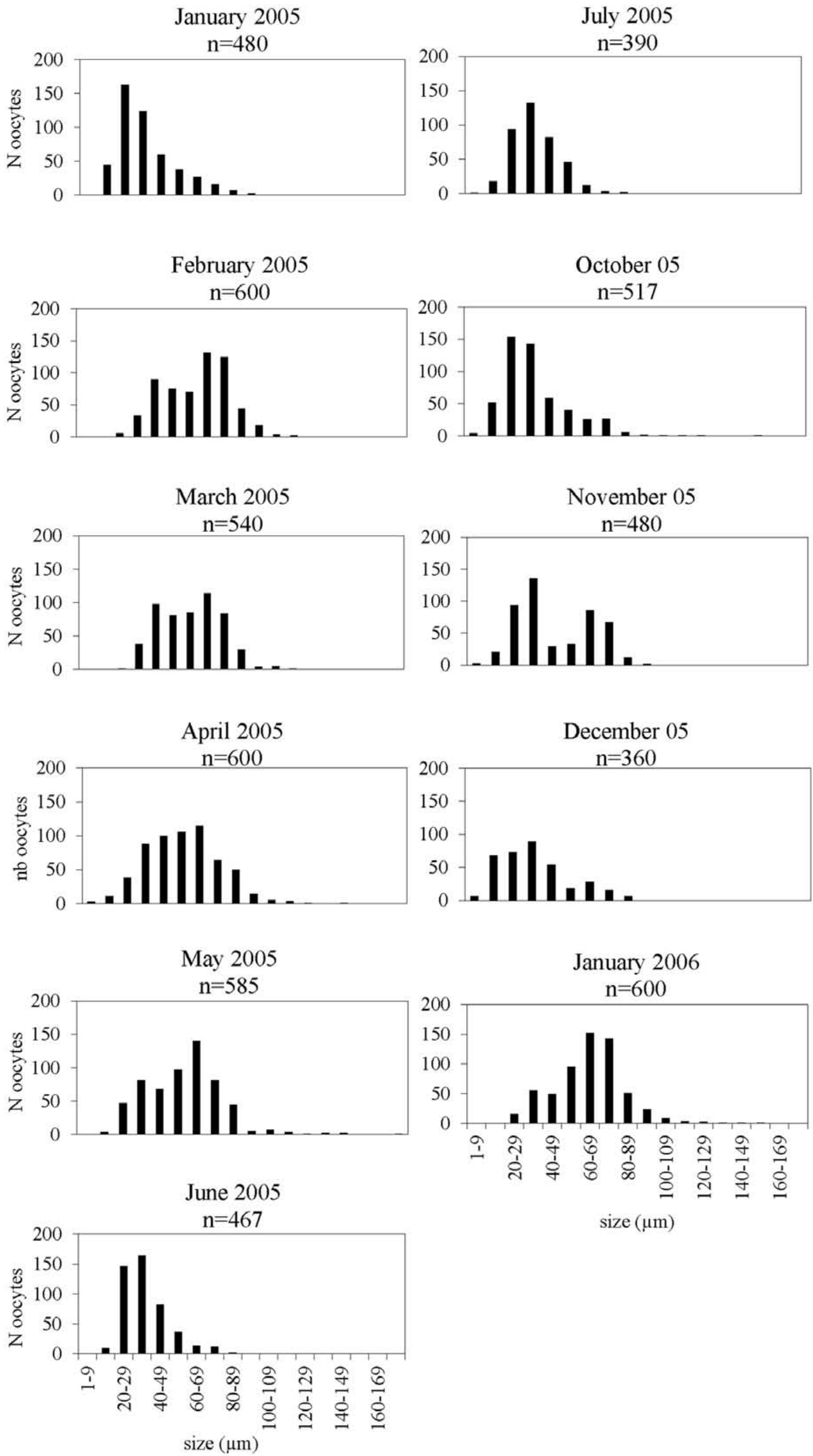

$\operatorname{size}(\mu \mathrm{m})$

Fig. 7. - Frequency distribution of the oocyte lengths during the whole study period. $\mathrm{N}$ indicates the number of oocytes measured. 
Table 3. - Monthly minimum (Min), maximum (Max), and average $( \pm \mathrm{SD})$ oocyte sizes per month throughout the study period. $\mathrm{N}$ is the number of oocytes counted out of the number of individuals indicated in the ind column.

\begin{tabular}{lccccc}
\hline & Min & Max & Average & $\mathrm{N}$ & ind \\
\hline January 05 & 15.08 & 98.68 & $36.62 \pm 16.03$ & 480 & 8 \\
February 05 & 15.55 & 119.83 & $59.14 \pm 19.21$ & 600 & 10 \\
March 05 & 19.41 & 115.79 & $55.37 \pm 17.80$ & 540 & 9 \\
April 05 & 7.87 & 140.43 & $56.00 \pm 20.11$ & 600 & 10 \\
May 05 & 18.67 & 171.34 & $58.21 \pm 20.80$ & 585 & 10 \\
June 05 & 15.08 & 88.97 & $37.02 \pm 12.54$ & 467 & 8 \\
July 05 & 8.00 & 82.65 & $37.50 \pm 12.31$ & 380 & 8 \\
October 05 & 8.94 & 156.21 & $37.76 \pm 18.56$ & 517 & 9 \\
November 05 & 7.77 & 97.44 & $46.47 \pm 20.08$ & 480 & 8 \\
December 05 & 8.43 & 87.81 & $36.03 \pm 18.08$ & 360 & 6 \\
January 06 & 23.29 & 152.78 & $64.74 \pm 18.35$ & 600 & 10 \\
\hline
\end{tabular}

gametes in different developmental stages. The highest frequency of oocytes (measuring $>60 \mu \mathrm{m}$ ) was seen in January $2006(64.33 \%)$.

In January 2005 most of the oocytes were small, coinciding with most of the females developing the gonad. In February and March 2005, the oocytes had grown and a few of them were pedunculated. In April and May 2005 there were small oocytes, observed in spawned C. chione (stage 4), and big oocytes in ripe smooth clams. In June and July 2005 the oocytes were small because the gonads were regenerating or degrading. The same stages were found in September 2005, when measurable oocytes with a visible nucleus were too few, so measurements could not be taken. October was similar to the summer months. In November, oocytes $60-79 \mu \mathrm{m}$ large were found in ripe gonads, and the largest oocytes were pedunculated; the smaller oocytes were found in females that were spawning or degrading the gonads. In December 2005 there were no pedunculated oocytes. Finally, in January 2006 most of the oocytes were large and ripe with some pedunculated oocytes, which were the largest oocytes found.

The monthly maximum, minimum, and average oocyte sizes per month are reported in Table 3. The length of the smaller oocytes found throughout the study ranged from $7.77 \mu \mathrm{m}$ in November 2005 to 23.29 $\mu \mathrm{m}$ in January 2006. The maximum oocyte lengths ranged from $82.65 \mu \mathrm{m}$ in July 2005 to $171.34 \mu \mathrm{m}$ in May 2005. Monthly mean oocyte diameter varied from $36.03 \pm 18.08 \mu \mathrm{m}$ (December 2005) to $64.74 \pm 18.35 \mu \mathrm{m}$ (January 2006). The highest average lengths were counted in months in which $C$. chione were ripe or spawning and the shorter average oocytes were found in the months in which the gonads were developing and/or degrading.

\section{DISCUSSION}

The bivalve $C$. chione is able to reproduce the whole year round with a spawning peak in spring. The gonadal development of this species had been previously studied through histological analysis on two occasions in the Mediterranean Sea (Valli et al. 1994, Tirado et al. 2002). In those studies, $C$. chione was also found to be capable of reproducing the whole year round. Tirado et al. (2002) observed three spawning peaks in southern Spain, finding the main emission of gonads in spring, as observed in our study. Valli et al. (1994) observed that the spawning period occurred in spring and summer in the Gulf of Trieste, with individuals increasingly spawning until a major peak in August. The gametogenic cycle of $C$. chione described in Portugal reported three spawning peaks and the release of the gametes lasted from January to October. Water temperature and nutrient supply are known to directly affect the physiological status of bivalves, regulating gametogenic cycles and spawning, among other physiological processes (Wilson and Hodgkin 1967, Hilbish and Zimmerman 1988, Gosling 2003, Morgan et al. 2013). In agreement with these studies, we found a very strong relationship between the amount of ripe individuals and the water temperature. Therefore, we hypothesize that the differences and similarities found between the gonadal cycle reported in the present study and the previous ones are most likely caused by temperature and food supply inter-site variations, though data on food supply are needed to support this hypothesis.

The sex ratio of $C$. chione was $1: 1$, as previously described in other populations (Tirado et al. 2002, Metaxatos 2004, Moura et al. 2008). Our study reports the first cases of hermaphroditism for $C$. chione. In the Veneridae, hermaphrodite individuals have been found in two different species, Ruditapes philippinarum (Delgado and Pérez-Camacho 2007, Lee et al. 2013), with frequency values similar to our findings (Drummond et al. 2006), and Megapitaria squalida (Romo Piñera et al. 2009). The high hermaphrodite frequency (between $21.8 \%$ and $23.5 \%$ ) for $M$. squalida was related to the low population density resulting from overfishing (Romo Piñera et al. 2009). The smooth clam population studied here was also affected by overfishing, but the frequency of hermaphrodites was much lower than what reported by Romo Piñera et al. (2009) for $M$. squalida. Therefore, we do not think that overfishing would cause hermaphroditism in $C$. chione, as hermaphroditic individuals have occasionally been found in bivalve species strictly considered gonochoric.

There are some discrepancies in the size of $C$. chione oocytes: whereas Metaxatos (2004) reported oocyte sizes ranging from 54.5 to $130 \mu \mathrm{m}$ and PérezLarruscain et al. (2011) described a mean oocyte diameter of 89.5 um under laboratory conditions, Moura et al. (2008) reported a ripe oocyte size of only $36 \mu \mathrm{m}$ diameter. Our results agree with the studies done in the Mediterranean Sea, i.e. Metaxatos (2004) and PérezLarruscain et al. (2011), finding bigger sizes which are in the size range of other venerid species (Mouëza et al. 1999, Chung 2007, Popović et al. 2013). The differences observed in the size of oocytes from Atlantic and Mediterranean smooth clam populations were related by Moura et al. (2008) to the tissue sample state (preserved or fixed) and also to genetic differences. The size of the sperm cells and acrosome agree with those described by Nicotra and Zappata (1991) in C. chione and are in the size range of other Veneridae species (Gwo et al. 2002).

Most of the $C$. chione dissected in the present study had developed sexual structures, in contrast to previ- 
ous studies, including the smallest bivalves analysed in both periods $(18.8 \mathrm{~mm}$ and $20.6 \mathrm{~mm}$ length in $2005-$ 2006 and 2014, respectively). Moura et al. (2008) reported that individuals might start spawning at $30 \mathrm{~mm}$ length, and the size at first maturity was estimated at a shell length of $50.81 \mathrm{~mm}$ on the southwestern coast of Portugal. In a later work, the same authors reported that C. chione needed more than four years to reach sexual maturation (Moura et al. 2009). In contrast, Metaxatos (2004) studied smears of $C$. chione gonads and reported that $25 \%$ of one-year-old smooth clams could be sexed, but gonadal maturation for the whole population began at the age of two years old. The author also reported that gonads were discerned in $C$. chione individuals larger than $12 \mathrm{~mm}$. Size at first maturity found in the Mediterranean for $C$. chione in this study is much smaller than that reported by Moura et al. (2008) in the NW Atlantic. There is no agreement on the best method for estimating the size at first maturity in bivalves, as there are differences in the method of observation of the gonads and/or the period of the reproductive cycle sampled. Some authors analyse histological sections of samples collected in the time period when adult specimens are ripe (Moura et al. 2008, Delgado et al. 2013), which requires previous knowledge of the reproductive cycle of the species. Other authors estimated the $\mathrm{SL}_{50}$ using samples collected monthly throughout one year, using two different methods: microscopic analysis of histological sections of the gonads (Camacho-Mondragón et al. 2012) or microscopic examination of smears of the sexual products (Derbali et al. 2009). Despite these differences, all methods are considered appropriate and commonly used for the $\mathrm{SL}_{50}$ estimation.

It is a common fisheries management practice to impose a minimum legal catch size greater than the size at first maturity, in order to allow the individuals to participate in spawning for some time before being fished (Williams and Babcock 2005). In this study we report a decrease in the $\mathrm{SL}_{50}$ for a $C$. chione population, which is to our knowledge the first mention in an overexploited bivalve population. We cannot assure that the nearly $9 \mathrm{~mm} \mathrm{SL}$ Sp decrease observed between 2005-2006 and 2014 was not affected by the different methodology used here to determine the value in each period, but the results are beyond the particular value and strongly suggest a downward trend. From a management point of view, this information is important to promote the periodical revision of this parameter as changes in the life history traits of the species occur over time. Changes in size and age at first maturity in many fish stocks often occurred after the stock abundances declined sharply. For example, after stock collapses in the early 1990s, both size and age at first maturity declined sharply for the cod (Gadus morhua) stocks in the northwest Atlantic (Saborido-Rey and Junquera 1998, Hutchings 2005). In mollusks, including gastropods and bivalves, differences in size at first maturity have been reported between populations of the same species (Hooker and Creese 1995, Cruz et al. 2000). In the gastropod Haliotis iris, such differences might be related to differences in growth rates between populations (Hooker and Creese 1995). Furthermore,
McShane and Naylor (1995) found differences in size at maturity and growth rate of the gastropod $H$. iris at small spatial scales between headlands and bays separated by as little as $200 \mathrm{~m}$. Cruz et al. (2000) reported that the differences in age and size at first maturity of the bivalve Argopecten ventricosus from two populations might be a consequence of both internal triggering mechanisms and environmental conditions. Changes in the biology of the species may also represent a plastic response to changes in the environment, such as compensatory density-dependence in growth and maturation, or a direct response of maturation to increased body condition or to temperature. In this study no environmental information was available (chlorophyll $a$, seston concentration), apart from surface sea water temperature, to investigate the possible causes for the reduction in $\mathrm{SL}_{50}$, but our results reinforce the need to revise this tool periodically to design management strategies.

\section{ACKNOWLEDGEMENTS}

This article is a result of the research project "Avaluació de l'estat del banc natural de petxina lluenta del Maresme" (Evaluation of the condition of the smooth clam bed in the Maresme) funded by the Department d'Agricultura, Ramaderia i Pesca (Generalitat de Catalunya) and the Dirección General de Costas (Ministerio de Agricultura, Alimentación y Medio Ambiente). We are grateful to the fisherman Mauricio Pulido for allowing us to board his boat Nautes. The histological process of the samples was performed by Dr. Francesc Padrós, from the Servei de Diagnòstic Patològic en Peixos, Faculty of Veterinary, UAB. The authors also thank "Puertos del Estado" (Ministerio de Fomento) for the environmental water temperature data. The coauthor Dr. Montserrat Ramón is part of a Consolidated Research Group (reference 2014 SGR 1383) of the Generalitat de Catalunya.

\section{REFERENCES}

Baeta M., Ramón M. 2013. Feeding ecology of three species of Astropecten (Asteroidea) coexisting on shallow sandy bottoms of the northwestern Mediterranean Sea. Mar. Biol. 160: 2781-2795.

http://dx.doi.org/10.1007/s00227-013-2270-0

Baeta M., Ramón M., Galimany E. 2014. Decline of a Callista chione (Bivalvia: Veneridae) bed in the Maresme coast (northwestern Mediterranean Sea). Ocean Coast. Manage. 93: 15-25. http://dx.doi.org/10.1016/j.ocecoaman.2014.03.001

Camacho-Mondragón M.A., Arellano-Martínez M., CeballosVázquez B.P. 2012. Particular features of gonadal maturation and size at first maturity in Atrina maura (Bivalvia: Pinnidae). Sci. Mar. 76: 539-548. http://dx.doi.org/10.3989/scimar.03522.05A

Chung E.E.-Y. 2007. Oogenesis and sexual maturation in Meretrix lusoria (Röding 1798) (Bivalvia: Veneridae) in Western Korea. J. Shellfish Res. 26: 71-80. http://dx.doiorg/10.2983/0730-8000(2007)26[71:OASMIM] 2.0.CO;2

Coen L.D., Brumbaugh R.D., Bushek D., et al. 2007. Ecosystem services related to oyster restoration. Mar. Ecol. Prog. Ser. 341: 303-307. http://dx.doi.org/10.3354/meps341303

Cruz P., Rodriguez-Jaramillo C.. Ibarra A.M. 2000. Environment and population origin effects on first sexual maturity of Catarina scallop, Argopecten ventricosus (Sowerby II, 1842). J. 
Shellfish Res. 19: 89-93.

Dame R.F. 1966. Ecology of marine bivalves: an ecosystem aproach. CRC Press, Inc. Boca Raton, Florida.

Delgado M., Pérez-Camacho A. 2007. Comparative study of gonadal development of Ruditapes philippinarum (Adams and Reeve) and Ruditapes decussatus (L.) (Mollusca: Bivalvia): Influence of temperature. Sci. Mar. 71: 471-484. http://dx.doi.org/10.3989/scimar.2007.71n3471

Delgado M., Silva L., Juárez A. 2013. Aspects of reproduction of striped venus Chamelea gallina in the Gulf of Cádiz (SW Spain): Implications for fishery management. Fish. Res. 146: 86-95. http://dx.doi.org/10.1016/j.fishres.2013.04.005

Derbali A., Jarboui O., Ghorbel M. 2009. Reproductive biology of the cockle Cerastoderma glaucum (Mollusca: Bivalvia) from the north coast of Sfax (Gulf of Gabes, Tunisia). Cienc. Mar. 35: 141-152.

Drummond L., Mulcahy M., Culloty S. 2006. The reproductive biology of the Manila clam, Ruditapes philippinarum, from the North-West of Ireland. Aquaculture 254: 326-340. http://dx.doi.org/10.1016/j.aquaculture.2005.10.052

Fiorito G., Gherardi F. 1999. Prey-handling behaviour of Octopus vulgaris (Mollusca, Cephalopoda) on bivalve preys. Behav. Process. 46: 75-88. http://dx.doi.org/10.1016/S0376-6357(99)00020-0

Galtsoff P.S. 1961. Physiology of reproduction in molluscs. Am. Zool. 1: 273-289. http://dx.doi.org/10.1093/icb/1.2.273

Gaspar M.B., Dias M.D., Campos A., et al. 2001. The influence of dredge design on the catch of Callista chione (Linnaeus, 1758). Hydrobiologia 465: 153-167. http://dx.doi.org/10.1023/A:1014587212528

Gofas S., 2013. Callista chione (Linnaeus, 1758). Accessed through: World Register of Marine Species.

Gosling E. 2003. Bivalve molluscs, biology, ecology and culture. Oxford, UK, 443 pp. http://dx.doi.org/10.1002/9780470995532

Gutiérrez J.L., Jones C.G., Strayer D.L., et al. 2003. Mollusks as ecosystem engineers: the role of shell production in aquatic habitats. Oikos 101: 79-90. http://dx.doi.org/10.1034/j.1600-0706.2003.12322.x

Gwo J.-C., Yang W.-T., Sheu Y.-T., et al. 2002. Spermatozoan morphology of four species of bivalve (Heterodonta, Veneridae) from Taiwan. Tissue Cell 34: 39-43. http://dx.doi.org/10.1054/tice.2002.0222

Hilbish T.J., Zimmerman K.M. 1988. Genetic and nutritional control of the gametogenic cycle in Mytilus edulis. Mar. Biol. 98: 223-228. http://dx.doi.org/10.1007/BF00391198

Hooker S.H., Creese R.G. 1995. Reproduction of Paua, Haliotis iris Gmelin 1791 (Molluscs: Gastropoda), in north-eastern New Zealand. Mar. Freshwater Res. 46: 617-622. http://dx.doi.org/10.1071/MF9950617

Hutchings J.A. 2005. Life history consequences of overexploitation to population recovery in Northwest Atlantic cod (Gadus morhua). Can. J. Fish. Aquat. Sci. 62: 824-832. http://dx.doi.org/10.1139/f05-081

Lee J.S., Park J.S., Shin Y.K., et al. 2013. Sequential hermaphroditism in Manila clam Ruditapes philippinarum (Bivalvia: Veneridae). Invertebr. Reprod. Dev. 57: 185-188. http://dx.doi.org/10.1080/07924259.2012.717109

Lindahl O., Kollberg S. 2009. Can the EU agri-environmental aid program be extended into the coastal zone to combat eutrophication? Hydrobiologia 629: 59-64. http://dx.doi.org/10.1007/s10750-009-9771-3

McShane P.E., Naylor J.R. 1995. Small-scale spatial variation in growth, size at maturity, and yield- and egg-per-recruit relations in the New Zealand abalone Haliotis iris. New Zeal. J. Mar. Fresh. 29: 603-612. http://dx.doi.org/10.1080/00288330.1995.9516691

Metaxatos A. 2004. Population dynamics of the venerid bivalve Callista chione (L.) in a coastal area of the eastern Mediterranean. J. Sea Res. 52: 293-305. http://dx.doi.org/10.1016/j.seares.2004.03.001

Morgan E., O’Riordan R.M., Culloty S.C. 2013. Climate change impacts on potential recruitment in an ecosystem engineer. Ecol. Evol. 3: 581-594. http://dx.doi.org/10.1002/ece3.419

Morton B., Peharda M., Harper E.M. 2007. Drilling and chipping patterns of bivalve prey shell penetration by Hexaplex trunculus (Mollusca: Gastropoda: Muricidae). J. Mar. Biol. Ass. U.K. 87: 933-940. http://dx.doi.org/10.1017/S0025315407056184

Mouëza M., Gros O., Frenkiel L. 1999. Embryonic, larval and postlarval development of the tropical clam, Anomalocardia brasiliana (Bivalvia, Veneridae). J. Mollus. Stud. 65: 73-88. http://dx.doi.org/10.1093/mollus/65.1.73

Moura P., Gaspar M.B., Monteiro C.C. 2008. Gametogenic cycle of the smooth clam Callista chione on the south-western coast of Portugal. J. Mar. Biol. Ass. U.K. 88: 161-167. http://dx.doi.org/10.1017/S0025315408000337

Moura P., Gaspar M.B., Monteiro C.C. 2009. Age determination and growth rate of a Callista chione population from the southwestern coast of Portugal. Aquat. Biol. 5: 97-106. http://dx.doi.org/10.3354/ab00119

Newell R.I.E. 2004. Ecosystem influences of natural and cultivated populations of suspension-feeding bivalve molluscs: a review. J. Shellfish Res. 23: 51-61.

Nicotra A., Zappata S. 1991. Ultrastructure of the mature sperm and spermiogenesis in Callista chione (Mollusca, Bivalvia). Invert. Reprod. Develop. 20: 213-218. http://dx.doi.org/10.1080/07924259.1991.9672201

Ostroumov S.A. 2005. Some aspects of water filtering activity of filter-feeders. Hydrobiologia 542: 275-286. http://dx.doi.org/10.1007/s10750-004-1875-1

Pérez-Larruscain J., Delgado M., Ignasi Gairín J. 2011. Larval growth and development of the smooth clam Callista chione (Mollusca: Bivalvia) under laboratory conditions. Cienc. Mar. 37: 271-277. http://dx.doi.org/10.7773/cm.v37i3.1902

Popović Z., Mladineo I., Ezgeta-Balić D., et al. 2013. Reproductive cycle and gonad development of Venus verrucosa L. (Bivalvia: Veneridae) in Kaštela Bay, Adriatic Sea. Mar. Biol. Res. 9: 274-284. http://dx.doi.org/10.1080/17451000.2012.731690

Poppe G.T., Goto Y. 1993. European seashells. Verlag Christa Hemmen, Germany.

Prins T.C., Smaal A.C., Dame R.F. 1998. A review of the feedbacks between bivalve grazing and ecosystem processes. Aquat. Ecol. 31: 349-359. http://dx.doi.org/10.1023/A:1009924624259

Pubill E., Abelló P., Ramón M., et al. 2011. Faunistic assemblages of a sublittoral coarse sand habitat of the northwestern Mediterranean. Sci. Mar. 75: 189-196. http://dx.doi.org/10.3989/scimar.2011.75n1189

Romo Piñera A.K., Ceballos-Vázquez B.P., García-Domínguez F., et al. 2009. Unusual high frequency of hermaphroditism in the gonochoric bivalve Megapitaria squalida (Sowerby, 1835) (Veneridae). J. Shellfish Res. 28: 785-789. http://dx.doi.org/10.2983/035.028.0407

Saborido-Rey F., Junquera S. 1998. Histological assessment of variation in sexual maturity of cod (Gadus morhua L.) at the Flemish Cap (north-west Atlantic). ICES J. Mar. Sci. 55: 515-521. http://dx.doi.org/10.1006/jmsc.1997.0344

Seed R., Suchanek T.H. 1992. Population and community ecology of Mytilus. In: Gosling E.M. (eds), The mussel Mytilus: Ecology, Physiology, Genetics and Culture. Elsevier Science Publishers B.V., pp. 87-169.

Tirado C., Salas C., López I. 2002. Reproduction of Callista chione L., 1758 (Bivalvia: Veneridae) in the littoral of Málaga (souther Spain). J. Shellfish Res. 21: 643-648.

Valli G., Marsich N., Marsich M. 1994. Riproduzione, biometria e contenuto di metalli in Callista chione (L.) (Mollusca, Bivalvia) del Golfo di Trieste nel corso di un ciclo annuale. Boll. Soc. Adriat. Sci. LXXV: 441-464.

Walker T.I. 1992. A fisheries biologists application of minimum legal lengths. In: Hancock, D.A. (eds), Workshop on Legal sizes and their use in Fisheries Management. Australia Government Public Service, pp. 47-50.

Williams J.R., Babcock R.C. 2005. Assessment of size at maturity and gonad index methods for the scallop Pecten novaezelandiae. New Zeal. J. Mar. Fresh. 39: 851-864. http://dx.doi.org/10.1080/00288330.2005.9517357

Wilson B.R., Hodgkin E.P. 1967. A comparative account of the reproductive cycles of five species of marine mussels (Bivalvia: Mytilidae) in the vicinity of Fremantle, Western Australia. J. Mar. Fresh. Res. 18: 175-204. http://dx.doi.org/10.1071/MF9670175 